\title{
The first wage round under the Labour Relations Act 1987: changing relative power
}

\author{
Raymond Harbridge and Stuart McCaw*
}

Labour's 1984 amendments to the Industrial Relations Act 1973 and the replacement of that act with the Labour Relations Act 1987 have altered the power relationship between employers and unions in private sector wage bargaining. It is argued that the changes favour employers. This paper examines the first private sector wage round negotiated after the passing of the 1987 Act offering a detailed analysis of all 588 documents, 246 of which were awards. A decline in the number of settlements overall is explained by the partial demise of formal second tier bargaining in the northern labour district, particularly in the manufacturing sector. Wage flexibility within the wage round is evidenced by 36 percent of settlements being either greater than 8.0 percent or lower than 7.0 percent. The authors conclude that employers have started to use their increased power in bargaining. Evidence for this is that employers were able to gain changes to hours of work provisions in 25 percent of settlements; resisted back-dating of wage settlements in a growing number of settlements; and were able to prevent any upwards wage drift in the settlements over the term of the wage round.

The FOL has made it clear that it is not going to be pushed around by big business interests, multinational corporation or any other monopoly that believes they have the support of Government in their efforts to weaken the trade union movement of New Zealand.

Excerpt from Jim Knox's FOL Conference Presidential Address (Knox, 1980, p.21)

\section{Introduction}

In early 1980 New Zealand's trade union movement basked in the glory of a major victory over Rob Muldoon's National Government. Following an eight week long stoppage at New Zealand Forest Products' pulp and paper plant at Kinleith, Tokoroa, the

Industrial Relations Centre, Victoria University of Wellington, $\mathrm{P}$ O Box 600, Wellington, New Zealand. This research was supported by grants from the New Zealand Planning Council, Victoria University's Internal Grants Committee and the Faculty of Commerce and Administration. The authors are grateful to the Chief Executive Officer and staff of the Arbitration Commission and the Registrar and staff of Union Rules; to the Editor and the journal's anonymous referees for their constructive comments on an earlier draft; and to Murray Robb and Ross Renner for computing assistance. 
Government revoked its decision to deny a composite wage settlement. This settlemen had been reached earlier by the combined unions and the company but was countermanded by the Government under the Remuneration (New Zealand Forest Products) Regulations, 1980 issud under the Remuneration Act 1979. The Government described the settlement as unacceptable on he grounds that it was excessive and reached as a result of strike action. In the ensuing dispute unions campaigned for the revocation of such interventionary powers, arguing that the government should stay out of wage fixing matters (Roper, 1982)

The Kinleith dispute and its resolution were to bring about the end of a wage system that had served New Zealand's private sector for some 90 years, for as part of the that her setlement betwin they would join in tripa 1980, p.10). That review took some years, but its end result has been to develop a system that has shifted the relative power away more strongly towards employers. Since Labour became Government in July 1984, two sets of changes to the wage fixing system have been made - in late 1984 there were major amendments to the Industrial Relations Act 1973 and further changes were made in 1987 with the passing of the Labour Relations Act. This paper reviews those major changes made to the private sector wage fixing system and examines
Relations Act 1987.

\section{Industrial conciliation and arbitration and its perceived faults}

The Industrial Conciliation and Arbitration Act 1894 had established the principles of a fixing in New Zealand - conciliation and arbitration. These principles have been developed and reinforced in subsequent legislation, most recently in the Industrial Relations Act 1973. Conciliation was a compulsory process of bringing the parties Rether to conciliation did not lead to a successful outcome, there was compulsory arbitration of the outstanding matters. From this system of conciliation and arbitration of disputes of interest a awards, there was the provision to be registered. These settlements almost always provided for better than award conditions, and were known colloquially as second tier agreements.

Second tier agreements fell into two types - those that were formal (that is registered with the Arbitration Court) and those that were informal (those not registered and thus not we court). The registered second tier settlements took two . VCAs were composite agreements were settlements between two or more unions and generally one employer usually on an industrial site. The development of second tier bargaining led to a situation where a worker could be covered by more than one document - the award and the second tier arrangement

On top of this "direct" bargaining, there was a (varying) system of adjustments to On top of this "direct 1919 to 1952 this was wages imposed by the Arbitration Court. In the period from 1919 to 1952 this was achieved by the Standard Wage Pronouncement and General Order mechanisms,

the 1960 s to 1980 s by the General Wage Order and Cost of Living mechanisms. lks over the failings and the future of this wage fixing system and whether in fact any "new" system could be developed (Brosnan, 1983). Most of these talks took place during "he period of a wage free imposed from June 1982 and lasting until December 1984. There was substantial agreement between the parties as to the perceived faults in the system (Bradford 1983, pp.14-17; Douglas 1983, p.24) How those perceived faults might eventually be resolved and the system redesigned presented significant difficulties. To understand the changes and the reasons for their implementation, it is first necessary to briefly discuss these perceived faults.

There were 7 major issues that the parties agreed were perceived faults. First it was believed that the system had become laboured by entrenched relativities. These relativities were of two types - relativities within an award (commonly referred to as margins for skill) and relativities between awards. Margins for skill have a long history and go back to the days of the Standard Wage Pronouncement. The margin for skill was the difference between the rate of pay set for a skilled tradesperson, a semi-skilled tradesperson and and unskilled labourer. As a percentage difference between skilled and unskilled rates of pay, these margins varied little over the years (Woods, 1963). The perceived fault of these relativities lay in the fact that it was difficult to move the wage rates of low paid workers without moving the better paid workers rates by the same percentage margin. However, relativities between awards had become an even more significant problem as many awards were linked to other awards by a series of Arbitration Court decisions on unsettled interes disputes. While employers and unions rarely invited the Court to rule on an unsettled wage dispute, until the late 1960s this was not so much through a lack of confidence in relativities. By the early 1980s wage bargaining had reached a point where once a handful of awards were settled at the start of a wage round, the other awards were believed to fall in line like a pack of dominoes, with each settlement moving by the same increment and independently of industry or occupational factors that might have indicated a need for reassessing traditional relativities.

Second, and linked to the issue of relativities, the role of arbitration and the Arbitration Court was considered a difficulty. Employers argued that the results of going to arbitration could be predicted, that the mechanism gave too much power to unions who did not need to bargain when they could go directly to Court, and that the Court had no criteria for resolving these unsettled disputes of interest. As a result, the Court tended to rely on either outdated relativities or on splitting claims down the middle. Further, some unions were opposed to compulsory arbitration on the grounds that they would achieve more through industrial action.

Third, the system failed because the reality of the award system was that the wage rates negotiated were "lowest common denominator" wage rates - the lowest minimum adult rate that the poorest employer could be expected to pay without going bankrupt. ${ }^{1}$ The overall result was that many workers were unable to live on the award wages they earned.

Fourth, employers argued that bargaining failed to take into account macro-economic issues such as the state of the national accounts and "what the country could afford". Unions argued for a greater say on social wage issues submitting that there was little point in negotiating a pre-tax weekly wage when they had neither control over how
government taxed that wage nor control over the social services that government offered. Government taxed that wage nor control over the social services that government offered. then workers would be obliged to take out medical insurance, a cost that should be offset against any pre-tax wage consideration.

Fifth, employers argued that there needed to be some rationalisation of bargaining so that they were not faced with multiple sets of bargaining - first at award and then at forma or informal second tier level. Employers argued that each worker should be covered by the results of just one set of negotiations.

Sixth, employers and unions agreed that composite and enterprise bargaining needed to
sults of just one set of negotiations.

1 It is worth observing that in the 1986/87 wage round 20 percent of all awards contained a minimum adult rate of pay lower than $\$ 5.25$ per hour - the then minimum adult wage set a minimum adult rate of pay lower than $\$ 5.25$ per hour - the then minimum adult wage set Family Support package of wage subsidies available to low income families. 
be encouraged but that such settlements should cover all workers on the site.

Seventh, there was general agreement that unions themselves needed to develop changed structures that would be more effective in their dealings with government, employers and their own members. Within that general agreement, however, there were very significant differences on what those new structures should be.

\section{Legislative change: December 1984}

In July 1984, the Labour party, solidly backed by the unions, won a handsome victory and became Government. At the Economic Summit held just two months after the election, the Minister of Labour was able to announce that the tripartite talks of the preceding 4 years had reached agreement and that wage bargaining would soon recommence under a modified wage-fixing system.

The changes implemented were designed to resolve the first 4 perceived faults of the system; relativities, arbitration, low minimum wages and social wage issues. First, and unsettled interest disputes voluntary rather than compulsory. This change allowed the possibility of an award lapsing should the parties not be able to agree on a settlement. possibility of an award lapsing should the parties not be able to agree on a settlement. Further it ensured that traditional relativities between awards could be broken where in award negotiations more strongly in the employers favour, yet it was a change confirmed by the National Executive of the New Zealand Federation of Labour, all of whom had been invited to attend the Economic Summit.

Second, where arbitration was voluntarily selected by the parties, the Arbitration Court Second, where arbitration was voluntarily selected by the
was given 5 market-led criteria, to guide it in its arbitrating.

Third, the Government introduced an annual Tripartite Wage Conference (TWC) to be held before each wage round. The TWC was designed to discuss a wide range of economic and social wage issues and it could issue a "guideline" regarding the level of desirable increment in the forthcoming wage round.

Finally, the Government agreed to increase the minimum wage specified in the Minimum Wage Act 1983. In September 1985, at the end of the 1984/85 wage round, Minimum Wage Act 1983 . In September $\$ 84$ per week (set in June 1981) to $\$ 170$ per week.

Radical though they were, there was limited opportunity for these changes to have any impact as within 18 months the Government had issued a green paper reviewing labour relations in New Zealand. In due course, the Government released a white paper summarining its intent, which was eventually formalised in the Labour Relations Act 1987 (Department of Labour, 1986).

\section{Wage bargaining and the Labour Relations Act}

The Labour Relations Act 1987 retains the changes implemented in 1984: voluntary arbitration criteria for that arbitration and the TWC. In terms of wage fixing, the new Act adrossed the fifth Act addressed the fither structures.

listed above: second tier bargaining, composite bargaining, and poor union structures.
The single most important feature of the Labour Relations Act 1987 is that it allows for just a single set of bargaining to take place for any group of workers. The provisions of Section 132A of the Act effectively outlaw second tier bargaining, forcing unions to decide whether each group of workers should be covered by an award or an agreement. Once a union decides that an employer should be party to an agreement and thus be Once a union decides the an employer shons under the award. For those unions that had been prolific users of second tier bargaining this presented a major difficulty.
Unions are encouraged to undertake composite bargaining arrangements under the Act. Should a union decide to discontinue a composite agreement, in contrast to the procedure for agreements, employer consent is not required to return to the relevant award coverage. There are some The old problem of one or two unions standing outside the composite bargaining arrangement and then bargaining separately with the employer is not addressed.

To encourage unions to develop better union structures the Government legislated that unions must be bigger and must have a minimum of 1,000 members to retain their registration. This meant some critical reorganisation for the 117 unions (just on 50 percent of all unions) that at 31 March 1987 had fewer than 1,000 members. The "bigger is better" argument for unionism is not new in New Zealand politics for the current Leader of the Opposition, Jim Bolger, discussed the pros and cons of such a move when he was Minister of Labour in 1980 (Bolger, 1982). Later in the decade, in contravention of International Labour Organisation Convention 87, (Freedom of Association) and under a different administration, the "bigger is better" argument won the day.

These were the major changes implemented but not the only ones. Others include: allowing the parties to develop the scope of bargaining by removing the "industrial matters" definition in the old legislation; the terms of settlements are no longer restricted to 12 months; the right to strike over interest disputes has been specifically made legal; the parties attending conciliation are no longer financially subsidised by the state; new administrative structures have been provided for with an Arbitration Commission handling the registration of wage bargaining arrangements and a Labour Court dealing with interpretation and other matters; a very limited form of competition between unions for members is allowed but only one union can have coverage of any one group of workers, and enforcement of registered settlements is now over to the parties and the Government has withdrawn its system of Labour Department award inspections.

In terms of structural change to the system the critical changes were those implemented in 1984 - particularly the removal of compulsory arbitration. The changes implemented in 1987 were designed largely to encourage unions toward industry bargaining, with the removal of second tier bargaining forcing some unions to consider moving to industry agreements rather than occupationally based awards.

\section{Bargaining trends under the Labour Relations Act}

One of the difficulties in analysing the success or failure of the legislative programme set in place in 1984 has been the absence of any hard data regarding successive wage rounds since 1984 and particularly since 1987 . New Zealand's wage bargaining system is a large and somewhat extensive one, yet one that goes largely unreported in day to day
media coverage. Thus it is possible for a small number of 'activists' in the wage bargaining arena to steal centre stage. Focusing on their activities can lead us to believe that significant change is occurring right through the system when this may not in fact be the case. Two trendsetting unions - the New Zealand Engineers Union and the New Zealand Distribution Workers Federation - were able to do this during the 1987-88 wage round. The Engineers Union is a significant player in the system being responsible for 145 of the 779 settlements reached in the 1986-87 wage round. As a prolific user of second tier bargaining and in a progressive move to re-organise their own union, an internal review was published (NZ Engineers Union, 1987). A memorandum to the 1987 NZ Metal Trades Award arranged for a working party to meet during the currency of the award with a view to splitting the award into a number of industry specific awards plastics industry, consumer products, heavy engineering etc. This memorandum attracted considerable media and academic interest. For example, in an important text on labour relations in New Zealand, Deeks and Boxall (1989) reprinted the memorandum in part and 
discussed the likely outcomes. The OECD, however, in its unique and splendid style went further. In its annual review of the New Zealand economy, they turned a promise of things to come into reality by stating :

Also, in the first major settlement under the new Act, the unions involved opted out of the national award system: the Metal Trades Award was modified to an industry-specific agreement. This resulted in various regional awards and

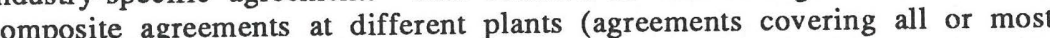
unions) (OECD, 1989, pp.45-46).

The OECD's analysis is demonstrably wrong on every account. The Engineers Union did not opt out of the national award system; the Metal Trades Award has not become an industry specific agreement; no new regional awards nor composite agreements at different plants have emerged. When the union and employers met at the outset of the 1988/89 plants he no radical change appears to be emerging in the short term, though on-going talks may lead to two new awards, a packaging industry award and a jobbing and contracting award,
being settled in the 1989/90 wage round.

The Distribution Workers Federation was party to a splitting of the New Zealand Drivers Award into 5 industry based awards, and two agreements - a genuine move from an occupationally based settlement to a series of industrially based settlements. It is believed that in the case of the drivers settlements, the employers were keen to see the believed that, in the case of the drivers changes wheas in the case of the metal trades setulemem enamoured with the unions suggestions. Changes such as commentators have suggested may well come about in the future, but to extrapolate from one or two cases (and one of them only a promise to change) is fraught with danger. The study reported here takes wider approach examining all settlements registered as part of the 1987/88 wage round.

\section{A database to examine bargaining trends}

Using data that combines publicly available information - information about documents registered by the Arbitration Commission; information about union registration from the Registrar of Union's office; information about industries and registations in New Zealand available from the Department of Statistics - it has been cccuplion of the methodology is pos occupational classifications along with the method for calculating the annualised wage occupational classifications
increment are appropriate

Each document was classified according to the New Zealand Standard Industria Classification (NZSIC) and the New Zealand Standard Classification of Occupation (NZSCO). The NZSIC divides industries into 9 major categories, each sub-divided at a digit level. For this study a two digit NZSIC classification was used. In applying the NZSIC, the major industry of the employer(s) party to each document was identified. A NZSIC, the major industry of the employer(s) party to each document was identified. A
business directory was used to assist in determining each employer's major industry (Fourth Estate Publications, 1987). Where possible, a single two digit NZSIC classification was applied. In many cases, however, it was not possible. Where

2 The database offers no estimate of the numbers of workers covered by each document. Such information is simply not available. Readers should be aware that some documen will apply to a mere handful of workers whereas some of the occupationally based awards will apply to a mere handul of works of may well applo to eachent and accordingly each document is treated as being of equal value. employers party to the document were in different industries, but fell within the same major category, a single digit NZSIC classification was applied. Where a document involved employers from two or more major categories the document was recorded as a multi-industry or craft document. Examining the major industry of the employer party to the document did not always lead to a simple application of the NZSIC classification. In the case of those predominantly larger employers that are involved in a variety of industries or who are vertically integrated throughout an industry, a close examination of industries or who are vertically integrated throughout an industry, a close examination of the document was made to ascertain whether it applied to only one part of the industries
covered. In other words the document itself and the industry to which it applied were the covered. In other words the document itself and the industry to which it applied were the
over-riding considerations in applying NZSIC classifications. The definition we have adopted of "industry" for the study is the leading business activity of the employers cited as party to the document insofar as that is relevant to the document itself.

To enable further examination of the craft or occupational base of each document, a NZSCO classification was applied. Morrison (1988) has re-grouped the NZSCO classifications into 9 major occupational groupings. We have further modified this by adding a digit for each of those major groupings, so we have used a 3 digit "new order" classification. To determine the NZSCO classification, the "industry", "wages" and "definitions" clauses of each document were examined to identify the range of occupations covered by each document. The same basic principles outlined in applying NZSIC classifications have been applied here. Accordingly, where the document was multioccupational, the major occupational grouping classification was recorded if those occupations all fell within the same major group and where the occupations fell into more than one of the major occupational groups the document was recorded as being "multioccupational". Some examples help explain the method we have used.

The Formica (NZ) Limited Employees Agreement (doc. 909) states in its industry clause that it shall apply to "all workers including maintenance staff employed by Formica (NZ) Limited, in connection with the making and conversion of raw materials into decorative and industrial laminates and related products". The pertinent NZSIC code is 35

- the manufacture of chemicals and of chemical, petroleum, coal, rubber and plastic products. In covering maintenance workers (fitters, turners, and machinists) the agreement covers workers in new order NZSCO group 222 - machinery fitters, machine assemblers etc.- but in also covering manufacturing workers it includes workers from group 216 - rubber and plastic product workers. The document is therefore classified as 200.

Local body documents have provided difficulties in determining the NZSIC classification. They are mostly multi-occupational, and often the range of occupations indicates that the local body is involved across industries, for example in public swimming pool operations (NZSIC 94), and in traffic administration (71). They therefore receive a multi-industrial classification. Alternatively, the Christchurch City Council Waterworks Shift Engineers and Municipal Electricity Department System Controllers Agreement (doc. 477) applies to specific workers in the MED and the Waterworks Division of the City Works and Planning Department. The MED is classified as 41 (electricity, gas, and steam), and the waterworks division as 42 (water works and supply) so the document is given the overall one digit classification of 40 . This document covers system controllers, shift engineers, system operators, and faults servicemen. The former two operate inside the control room and the latter in the field. A distinction is made between those that get their "hands dirty", and those that do not. Those that do are classified in the 200's as maintenance engineers and electricians, whereas the others are grouped with architects, engineers, and related technicians (new NZSCO 762). The document therefore receives a multi-occupational classification.

One final example is the New Zealand Metal Trades Award (doc. 247). It is classified as both multi-industrial and multi-occupational. It covers boilermakers, toolmakers, fitters and turners (200), as well as quality control inspectors, spray painters, and crane drivers (300). These people work in a range of industries from engineering contracting 
(52), straight engineering (38) to plastic manufacturing (35).

Comparing wage increments in different documents is far from simple. In comparing wage settlements a number of factors need to be considered. Unions and employers have developed a great number of techniques for disguising just how flexible their settlements are. They can, for example, agree on the "going-rate" in any particular wage round but agree to a shorter or longer term than 12 months and/or agree to the "going-rate" but fail to backdate the document. Both of these techniques are widely used to increase the level of flexibility of wage settlements. Other types of settlements we have encountered involve stepped increments, for example, 6 percent for the first 6 months and 3 percent for the next 6 months. There are endless variations of stepped settlements but fortunately they are comparatively rare occurrences. We calculate the value of the settlement accounting for issues such as stepped settlements, other than 12 month terms and failure to backdate settlements. We postulate that a settlement that is not backdated is worth less than one of (he same wage increment for 12 months; that the compounding effect of a stepped settlement needs to be taken into account in the same way that a bank calculates compound interest on savings. A full explanation of the technique can be found in Brosnan and Harbridge (1988).

In the analysis below, we have selected in each document to examine the raw percentage increment over the previous document for the rate that most workers are likely to be employed on. In other words we are attempting to track the general level of settlement in a document rather than pick up specific differences.

\section{The 1987/88 wage round: the results}

The first document relating to the 1987/88 wage round was registered by the Arbitration Commission in September 1987 and the last in March 1989 - effectively this wage round, like earlier ones, lasted 18 months. In that period there were 684 documents registered. Of these, 96 were documents registered for the first time with the Arbitration registered. Of these, 96 were documents registered for the first time with the Arbitration
Commission, having previously been state sector determinations issued under the provisions of the State Service Conditions of Employment Act 1977. These "state" documents were simply transitional documents that codified the existing wages and conditions operating in a particular area of the state. For the purposes of the analysis in this paper, we have not included these "state" documents.

There were 588 private sector documents registered in the 1987/88 wage round. Of these 277 were agreements, 246 were awards, 29 were composite awards and 36 were composite agreements. Altogether there were 191 fewer settlements in the 1987/88 wage round compared with the 1986/87 wage round. There were 38 fewer awards or composite awards, 112 fewer agreements and 17 fewer composite agreements. There were no this type of settlement in the Labour Relations Act 1987. The types of documents being registered by the Commission are presented in Table 1.

Table 1: Private sector document types in the $1986 / 87$ and $1987 / 88$ wage rounds.

\begin{tabular}{lcc} 
Documents & $1986 / 87$ & $1987 / 88$ \\
\hline Awards & 313 & 246 \\
VCAs /Agreements & 389 & 277 \\
COAs & 53 & 36 \\
Composite awards & - & 29 \\
VAs & 24 & - \\
\hline Totals & 779 & 588
\end{tabular}

For the purposes of this analysis the wage round has been split into three 6 month periods: September 1987 to February 1988, March 1988 to August 1988 and September 1988 to March 1989. There were 162 documents registered in the first 6 months, 320 in the second and 106 in the third.

A registered union was party to 450 settlements, with multi-union groups and associations settling 78 and 59 documents respectively. The impact of the "1,000" membership rule was quick, with just 68 settlements being made by unions with less than 1,000 members. At the other end of the scale, 319 documents (54 percent of all documents) were settled by unions with more than 10,000 members.

The labour district of each settlement was recorded. Many settlements were multidistrict without being national settlements and we have separated each of these multidistrict settlements by each individual district. Associated with the overall decrease in the number of settlements in the system and the decline in the negotiation of formal second tier settlements such as VCAs and COAs, there is a very large decline in document settled in the northern labour district as is shown in Table 2.

Table 2: Private sector documents by labour district in the 1986/87 and 1987/88 wage rounds.

\begin{tabular}{lcc} 
Labour districts & $1986 / 7$ & $1987 / 8$ \\
\hline New Zealand & 163 & 136 \\
Northem & 304 & 194 \\
Taranaki & 97 & 86 \\
Wellington & 204 & 151 \\
Marlborough & 62 & 56 \\
Nelson & 74 & 70 \\
Westland & 42 & 45 \\
Canterbury & 169 & 135 \\
Otago/Southland & 111 & 102
\end{tabular}

Industry and occupational bargaining

New Zealand Standard Industrial Classification (NZSIC) and New Zealand Standard Occupational Classification (NZSOC) two digit classifications (1987/88 wase rifications were applied to the in the previous wage round are presented in Appendix 1 . The compared with settlements or multi-industrial bargaining. from 84 (just 10.5 percent 88 documents (15 percent of all documents in 1987/88). The documents in 1986/87) to is in the manufacturing of decline of bargaining the the mere 359 documents in the manufacturing sector but this has dropped to just 250 documents. The other sector to show an appreciable decline in bargaining was the transport sector ( 94 documents decline
to 45 ).

Documents registered in 1986/87 and 1987/88 and their NZSOC classifications are presented in Appendix 2. The dramatic changes away from industrial bargaining The the only occupational classification to experience a large drop in settlements was "fitters" where only 10 documents were registered compared with 34 in the previous wage round, There has been some growth of industrially based bargaining in the 1987/88 wage round. as is demonstrated by the growth of multi-occupationally based percentage of the total settlements recorded, multi-occupational documents grew from 45 percent to 52 percent from $1986 / 87$ to $1987 / 88$. 


\section{Wage increments}

In our analysis of wage increments we were forced to exclude 123 of the settlements from the sample. Primarily this was because there were 49 new documents negotiated where no increase could be recorded. Further there were 41 documents renegotiated from an earlier document which had run well past its expiry date, 24 documents which moved by a pre-determined state linkage provisions and the 7 documents that moved by a fla monetary payment rather than a percentage increment.

In this wage round 62 settlements were not backdated - this represents 12.5 percent of all renegotiated settlements. Of the settlements that were not backdated, 24 were awards about 10 percent of all renegotiated awards. Settlements falling in the lowest decile were significantly less likely to be backdated than were settlements falling in other deciles (Chisquare $=146.172 \mathrm{df}=6 \mathrm{p}<0.0001$ ).

There is no longer a requirement that wage settlements be for a minimum period of 12 months. The vast majority of settlements (nearly 80 percent) were settled for exactly a 12 month term. There were only 6 settlements with terms of less than 6 months, and 80 settled for less than 12 months. Comparatively few settlements - just 44 - were settled for longer than a 12 month term. The terms of awards were no different from other types of documents.

The lowest adult rate of pay in each settlement was determined in 583 of the settlements. The range of lowest weekly wage settlements was very diverse, ranging from a low of $\$ 142$ per week in one settlement (Otago and Southland Oyster Openers and Other Depot Employees Award) to a high of $\$ 989$ per week in another (New Zealand Merchant Service Guild (Offshore Oil/Gas Operations). There were 20 settlements (13 of which were awards) that provided for an adult rate of pay lower than the legal minimum wage of $\$ 225$ per week. Fifty percent of all settlements provided for a minimum wage of $\$ 305$ per week or less and 30 percent provided for a rate of $\$ 280$ or less per week. Awards provided for lower minimum rates than other types of settlements. Fifty percent of awards provided for a minimum rate of $\$ 280$ per week or less and 80 percent of all awards provided for a minimum rate of $\$ 320$ per week or less.

In the $1987 / 88$ wage round, there was a definite wage path around the 7.0 percent mark with 152 documents being settled for exactly 7.0 percent. There was a wide dispersion of settlements with 3 settlements (all awards and all in the agricultural sector) registering a 0 percent wage rise and 4 settlements being measured at over 20 percent. There were 56 documents (46 of which were awards) settled for less than 7.0 percent and 161 (70 of which were awards) settled at 8 percent or over. The mean wage increase for agreements was 8.2 percent; for awards 7.6 percent; for composite awards 7.5 percent and for composite agreements 7.1 percent.

Industry differences in wage settlements that emerged in the 1986/87 wage round were apparent in the 1987/88 wage round as well. Industries that achieved higher than averag wage settlements in 1986/87, such as manufacturing, transport and communication and the public service, continued to do comparatively well. Other industries that had lower than average wage settlements in the 1986/87 wage round, such as wholesale and retail and the finance sector, continued to fare poorly. The figures for mean wage increment by industrial sector and occupation in the 1986/87 and 1987/88 wage rounds are in Tables 3 and 4.
Table 3: Mean wage increment by industrial sector by wage round

Industrial Sector

$1986 / 87$

\section{Agriculture}

Mining

$6.46 \%$

Manufacturing

Energy

$7.37 \%$

$7.45 \%$

$7.30 \%$

Construction

$7.00 \%$

Wholesale and Retail $\quad 6.94 \%$

Transp / Communication $7.60 \%$

Finance $\quad 6.96 \%$

Public Service $\quad 7.21 \%$

$7.34 \%$

$4.44 \%$

$7.82 \%$

$7.91 \%$

$8.03 \%$

$7.34 \%$

$7.60 \%$

$7.60 \%$

$7.36 \%$

$7.77 \%$

Multi industrial

$7.86 \%$

Table 4: Mean wage increment by occupation by wage round

\begin{tabular}{lll} 
Occupational class. & $1986 / 87$ & $1987 / 88$ \\
\hline Extractive Craft & $6.70 \%$ & \\
Transformative Craft & $7.12 \%$ & $5.59 \%$ \\
Ext and Trans Support Staff & $7.45 \%$ & $7.16 \%$ \\
Marketing & $6.83 \%$ & $7.28 \%$ \\
Management & $5.80 \%$ & $6.80 \%$ \\
Service Support & $7.67 \%$ & $7.93 \%$ \\
Producer service 'crafts' & $7.73 \%$ & $9.10 \%$ \\
Social service 'crafts' & $9.06 \%$ & $8.50 \%$ \\
Personal service 'crafts' & $7.76 \%$ & $7.88 \%$ \\
Multi-occupational & & \\
& $7.32 \%$ & $7.71 \%$
\end{tabular}

Position in the wage round and changes to hours of work

Of the documents that were being renegotiated from a settlement in the 1986/87 wage round, awards tended to be settled earlier in the wage round than were agreements. The first 6 months saw 37 percent of all awards registered but only 24 percent of agreements. In the last 6 months of the wage round, only 12 percent of awards but 22 percents. agreements were registered. These differences were not however statistically percent of Settlements registered early in this wage round did no worse than settlements registered in the second and third 6 months of the round. This contrasts with the 1986/87 wage round where unions which settled later did better than those that settled early in the round.

Of the 466 documents negotiated in the 1986/87 wage round and re-negotiated in the $1987 / 88$ wage round, 129 ( 28 percent) had a change to the hours of work clause. 42 (19 percent) of the 224 renegotiated awards contained such a change. Agreements were significantly more likely to contain a change to the hours of work clause than were awards (Chisquare $=32.485 \mathrm{df}=9 \mathrm{p}<0.0001$ ). A change to the hours of work clause did not lead to a significantly higher level of settlement than was recorded in documents where there was no change to the hours of work clause. Again this differed from the 1986/87 wage round where changes to hours of work were "compensated" by a higher level of wage
increment 


\section{Discussion}

There are a number of important trends that emerge from the data presented on this, the first first we system than in the 1986/87 wage round. There were 191 percent fewer documets fewer private sect documents to be removed from the system were VCAs - the by these VCAs and the "second tier" agreements. Workers originally covered by both these VCAs and the appropriate parent award are now covered by just that parent award. VCAs have a long history of being concentrated in the north and in the manufacturing sectors (Young 1983, Harbridge, 1986). It is no surprise then that there are now 110 fewer documents applyin Hin the Northerctoring sector.

Second, while the legislation provides unions with incentives to enter composite Second, while the legislation printer agreements, the number of composite agreements increased. This is a surprising finding as a survey of unions underten wage round had established that composite bargaining was a preferred optin for my of them (Harbridge, 1988b). That there was a decline in composite bargaining is worthy of further research, but the decline could indicate not inconsiderable employer resistance to further research, but the it is presently designed.

The little change in occupational bargaining, Third, the 1he system. There was, however, a notwithstanding the overall decline of documents in the change in industry bargaining. Conventional wisdom about New Zealon had been that the system was craft or occupationally based. We have clear evidence that, taken as a whole, the system is in fact industrially rather than craft based. Our analysis of 1986/87 wage round demonstrated that 90 percent of all documents were able to be the 1980 dit 45 percent of al classified with a on single occupation documents. In the documents were multi-occusation $1987 / 88$ wage round only 85 percent were given and the has and 52 percent of documents were multi-cecupational. This data imples that there has been in the first round under the Labour Relations Act, a consolidation of the occupa a

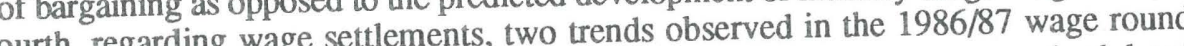
Fourth, 12.5 pere continued. 12.5 percent in the 1986/87 round), and industry different in the 1987/88 wage did occupationally based settements. The factor that was diferent over time as it had the round was that the level of wage settlements did not drift upwards over time as it had the year before. In the 1986/87 round, documents settled early in the round received the lowest wage increments. In the 1987/88 wage round, position in the wage round did not offect the level of settlements. This indicates that the employers were able to "hold the line" in lo round, something they have not always bee line "in wage settlen there is evidence of considerable able to do. Notwithstanding a "Wage path" flexibility in the system with one third of settements being eitsiles than had existed in more than 8.0 percent. However, this represented less flexibility than had exised in 1986/87. With the exception of different settements across labour distriets and between industrial sectors, there are no apparent differences by oher variables. It might have been industrial sectors they did, with agreemen expected that agreement at an average of 7.6 settling for an average 8.2 peros did no better than single percent. Multi-union groups bargaining in a compos badly as in the 1986/87 round. unions negotiating awards and associations did not fare as badly as in

Finally, size of union made no difference to the level of settlement.

Fifth, an interesting trend relating to hours of work provisions emerged. We can change to their hours of work clause, in the $1987 / 88$ round over 25 percent, or over one document in 4 , had a change in the hours of work clause. Further, as we have already observed, changes to the hours of work provisions in documents were not "sweetened" by additional wage payments as was the case in the 1986/87 wage round. The data suggests that employers have been partially successful in settling for more flexible hours of work arrangements.

\section{Conclusion}

The Labour Relations Act 1987 continued the process of wage bargaining reform initiated in 1984. Some limited evaluation of the success of the reforms is possible by examining the "perceived faults" of the old system referred to earlier in relation to the bargaining outcomes in the 1987/88 wage round.

The major thrust of those reforms was to break up the existing patterns of relativities between settlements and to encourage industry and site bargaining. The reforms also radically altered the balance of power away from unions and towards employers by removing the option of compulsory arbitration of unsettled interest disputes and allowing the possibility of awards lapsing.

In the 1987/88 wage round no unsettled dispute of interest under the Labour Relations Act 1987 was voluntarily referred to arbitration but no awards appear to have lapsed as a result. Relativities between documents have shown no greater range than in previous wage rounds and if anything our data suggests that relativities between settlements have tightened rather than loosened. The effective destruction of an extensive layer of second tier bargaining in the Northern labour district's manufacturing sector will lead to a greater reliance on award settlements in future wage rounds and thus less flexibility in wage settlement patterns. There is of course the possibility that informal (i.e. unregistered) bargaining is still taking place and giving collective "second tier" benefits to unionists, though the likelihood of this is low under the principle of a single set of negotiations contained in S132 of the Labour Relations Act. Section 152 of the Act allows an employer, who is requested by a union or a group of workers to undertake additional bargaining following an award settlement, to seek exemption from the award. Unions are well aware of the dangers to the national award system of having employers seek such exemptions and it is our observation that they have tended to restrict their informal bargaining (Harbridge, 1988b)

Whereas the legislation implies incentives for composite and industry bargaining, there is no evidence that industry and composite bargaining is increasing. In fact, the reverse appears to be the case and as unions have moved to consolidate the award system the numbers of composite agreements and industry based settlements have declined while the numbers of occupationally based settlements have increased.

Finally, it is worth commenting that our data suggest that employers exercised some of their increased power in the 1987/88 wage round. While they appeared not to have forced the "collapse" of any award in the wage round, they were very successful in three areas. First, they achieved changes to 25 percent of the hours of work clauses in settlements. They achieved this without conceding additional wage payments as compensation for those changes as had been necessary in the 1986/87 wage round. Second, employers were successful in holding the "wage path" for the duration of the wage round rather than allowing settlements to drift upwards as the round progressed. Third, employers were able to resist the back-dating of settlements in an increasing number of cases.

The changes implemented in 1984 and 1987 altered the legislative balance of power in wage bargaining away from unions and toward employers. Our findings suggest that employers have started to use that initative. FOL president, Jim Knox had warned that following the Kinleith dispute, unions would not be pushed around by "big business" and 
(1982, p.7) argued that in 1980 the unions entered the tripartite talks on the wage fixing system in a strong position to take the initative during the talks. When Labour won the election in July 1984 with significant union backing, the unions should have been able to strengthen their position. Yet despite their apparent strong position, the unions agreed by September 1984 to changes that fundamentally altered the balance of bargaining power. By this time Finance Minister Roger Douglas was firmly in control of the New Zealand economy and began cutting a deregulatory swathe through a tightly regulated economy affecting all sectors. During his first term in office, Douglas implemented policies aimed at improving New Zealand's international comparative trade position by lowering domestic inflation. Microeconomic tools included tightening the money supply and removing sectoral subsidies. In particular, the agriculture and manufacturing sectors have struggled, especially in the face of high interest rates and an over-valued dollar. New Zealand moved into an economic recession measurable by a rapid increase in structural unemployment. Unions suffered from this economic downturn. They too learned that, contrary to their expectations, political support for their objectives was not necessarily forthcoming. The return of compulsory unionism, abolished by the National Government in 1983, was achieved, but at the cost of losing compulsory arbitration. The removal of compulsory arbitrat co the cost the current economic climate has given employers the power to refuse to renegotiate Refinen

Refinements to the system since 1984 have further altered the balance of bargaining power away from unions, and employers in the new economic climate are now exercising that power. That the unions were persuaded to give away so much so early in the rule of the Labour Government and that employers only started exercising their new found strength in the 1987/88 wage round are topics worthy of further research.

Appendix 1: The 1986/87 and 1987/8 wage rounds : private sector documents by 2 digit NZSIC classification

$1 \quad$ Agriculture
$\begin{array}{ll}11 & \text { Agriculture and hunting } \\ 12 & \text { Forestry and logging }\end{array}$
13 Fishing

$2 \quad$ Mining

$\begin{array}{ll}21 & \text { Coal mining } \\ 22 & \text { Crude petroleum and natural gas } \\ 23 & \text { Metal ore mining } \\ 29 & \text { Other mining }\end{array}$

$3 \quad$ Manufacturing

31 Manuf. food beverages and tobacco

32 Textile wearing apparel and leather goods

33 Manuf. wood, wood products, furniture

34 Manuf. paper, printing and publishing

35 Manuf. chemicals and of chemical, petroleum coal, rubber and plastic products

36 Manuf. non-metallic products

37 Basic metal industries

38 Manuf. metal products, machinery and equip
$1986 / 87 \quad 1987 / 88$

1

6 Appendix 1 (cont.): The $1986 / 87$ and $1987 / 8$ wage rounds : private sector documents
by 2 digit NZSIC classification

$1986 / 87$

$1987 / 88$

39 Other manufacturing industries

4 Energy

41 Electricity gas and steam

42 Water works and supply

Construction

51 Buildings

52 Construction other than buildings

53 Ancillary building and construction services

5

1

Wholesale and Retail
61 Wholesale trade
62 Retail trade
63 Restaurants and hotels

7 Transport and Communication

71 Transport and storage

72 Communication

8 Finance

\section{$81 \quad$ Financing}

82 Insurance

83 Real estate and business services

9 Public Service

91 Public administration

92 Sanitary and similar services

93 Social and related community services

94 Recreational and cultural services

95 Personal and household services

96 International and extra-territorial bodies

Subtotal

695

500

Craft or multi-industry documents

Total
2
2

88

3

8

45

15

3

11

43

19

588 
Appendix 2: The 1986/87 and 1987/88 wage rounds: private sector documents by "new order" NZSCO classification.

\section{Extractive Craft}

\section{Farmers}

Agricultural and animal husbandry workers

Fishermen, hunters and related workers

Forestry workers

Miners, quarrymen, well drillers related workers

\section{Transformative Craf}

Food and beverage processors

Tobacco preparers \& tobacco product makers

Spinners, weavers, knitters, dyers related workers

Tanners, fellmongers \& pelt dressers

Tailors, dressmakers, sewers, upholsterers

Shoemakers and leather goods makers

Cabinet makers and related woodworkers

Wood preparation workers and paper makers

Paper and paper board products makers

Printers and related workers

Rubber and plastic product makers

Chemical processors and related workers

Glass formers, potters and related workers

Metal Processors

Plumbers welders sheet-metal structural, erectors Blacksmiths toolmakers machine tool operators Machinery fitters machine assem, precision instr. Stonecutters and carvers

Jewellery and precious metal workers

Electrical fitters and related electrical, electronics

Stationary engine and related equipment operators Bricklayers carpenters,other construction workers

3. Extractive \& Transformative Support Staff

Production and related workers

Painters

Material handling \& equipment operators dockers Labourers

Transport equipment operators

\section{Marketing}

Sales supervisors and buyers

Technical sales, commercial travellers, agents Insurance, real estate, securities, services, sales Salespersons, shop assistants and related workers Sales workers not elsewhere classified

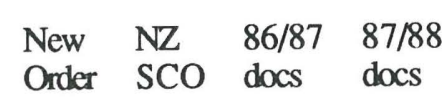

$\begin{array}{rrr}101 & 61 & - \\ 102 & 62 & 13 \\ 103 & 64 & 1 \\ 104 & 63 & - \\ 105 & 71 & 1\end{array}$

200
Appendix 2 (cont.): The 1986/87 and 1987/88 wage rounds: private sector documents by "new order" NZSCO classification.

$\begin{array}{llll}\text { New } & \text { NZ } & 86 / 87 & 87 / 88\end{array}$

Working Proprietors

Working proprietors (wholesale and retail)

Working proprietors (catering lodging services)

5 Management

Farm managers and supervisor

Legislative officials, government administrator Managers

Managers (wholesale and retail trade)

Managers (catering and lodging services)

Management Support

Production supervisors and general foremen Clerical supervisors

\section{Service Support}

Professional, technical and related workers Legislative officials, government administrators Stenographers, typists, card punch operators

Bookkeepers, cashiers and related workers

Computing machine operators

Clerical and related workers not incl elsewhere Protective Service Workers

Building caretakers, cleaners and related workers

Transport and communications supervisors

Transport conductors

Mail distribution clerks

Telephone and telegraph operators

Broadcasting station, sound-equipment operators

Service workers not elsewhere classified

7. Producer Service 'Crafts'

Aircraft and ships officers

Architects, engineers and related technician

Statisticians, mathematicians, systems analysts etc

Economists

Accountants

Jurists

\section{Social Service 'Crafts'}

Physical scientists and related technicians Workers in religion

Teachers

ife scientists and related technicians

Medical, dental, veterinary and related workers

\section{Order SCO docs docs}

$\begin{array}{llll}438 & 42 & - & - \\ 439 & 51 & - & - \\ 500 & & 4 & - \\ 540 & 60 & - & - \\ 541 & 20 & - & - \\ 542 & 21 & 1 & 1 \\ 543 & 40 & - & - \\ 544 & 50 & - & - \\ 545 & 70 & 3 & 1 \\ 546 & 30 & - & -\end{array}$

600

ts


Appendix 2 (cont.): The 1986/87 and 1987/88 wage rounds: private sector documents by "new order" NZSCO classification.

\section{Personal Service 'Crafts'}

Authors, journalists and related writers

Sculptors, painters, photographers, related artists Composers and performing artists

Athletes, sportsmen/women and related workers

Housekeeping and related service supervisors

Cooks, waiters/waitresses, bar, related workers

House staff related housekeeping service workers

Launderers, dry-cleaners and pressers

Hairdressers, barbers, beauticians related workers

$$
\begin{array}{ll}
\begin{array}{ll}
\text { New } \\
\text { Order }
\end{array} & \text { NZ } \\
& \text { SCO } \\
900 & \\
& \\
972 & 15 \\
973 & 16 \\
974 & 17 \\
975 & 18 \\
976 & 52 \\
977 & 53 \\
978 & 54 \\
979 & 56 \\
980 & 57
\end{array}
$$

Multi-occupational documents

Total

\section{References}

Bolger, Hon J B (1982) Commentary : the Government's role in industrial relations New Zealand journal of industrial relations 7(1):35-37.

Bradford, Max (1983) A private sector employer view. In Brosnan P (ed) The future of wage fixing Wellington, Industrial Relations Centre, Victoria University of Wellington.

Brosnan, Peter (1983) Tripartite wage agreement - a feasible objective? In R A Buckle (ed) Inflation and economic adjustment. Wellington, Victoria University of Wellington.

Brosnan, Peter and Harbridge, Raymond (1988) When is 3 plus 1 equal to 3.25? - Three methods of examining wage settlements to determine their annual rate of adjustment. Industrial Relations Centre Working Paper 6/88, Victoria University of Wellington.

Department of Labour (1986) Government policy statement on labour relations Wellington, Government Printer.

Deeks, John and Boxall, Peter (1989) Labour relations in New Zealand Auckland, Longman Paul.

Douglas, Ken (1983) A private sector union view. In Brosnan P (ed) The future of wage fixing Wellington, Industrial Relations Centre, Victoria University of Wellington.

Fourth Estate Publications (1987) New Zealand Business Who's Who Fourth Estate Publications, Wellington.

Harbridge, Raymond (1986) Collective second tier bargaining in New Zealand New Zealand journal of business 8:40-55.

Harbridge, Raymond (1988a) The way we were - a survey of the last wage round negotiated under the Industrial Relations Act 1973 New Zealand journal of business $10: 48-65$

Harbridge, Raymond (1988b) Whatever happened to second tier settlements? A survey of settlements under the Labour relations Act 1987 New Zealand journal of industrial relations 13(1):143-156.

Knox, Jim (1980) Presidential address to conference Minutes and report of the proceedings of the forty third annual conference Wellington, New Zealand Federation of Labour.

Morrison, Philip S (1988) Access, employment structures and local labour markets New Zealand population review 14(1):34-50

New Zealand Engineers Union (1987) Strategies for change Wellington, New Zealand Engineers Union.

OECD (1989) OECD economic surveys : New Zealand OECD, Paris.

Roper, Karen (1982) The impact of Remuneration Act 1979 - 1980 New Zealand journal of industrial relations 7(1):1-12.

Roth, Bert (1980) Industrial relations chronicle New Zealand journal of industrial relations $\mathbf{5}(1): 1-12$.

Woods, Noel S (1963) Industrial conciliation and arbitration in New Zealand Wellington, R E Owen, Government Printer.

Young, F J L (1983) Registered voluntary collective agreements in New Zealand New Zealand journal of industrial relations 8(1):31-38. 


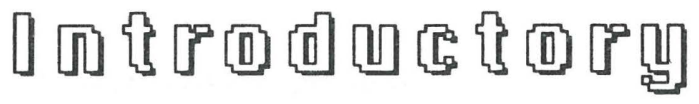

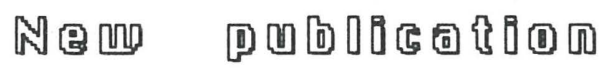

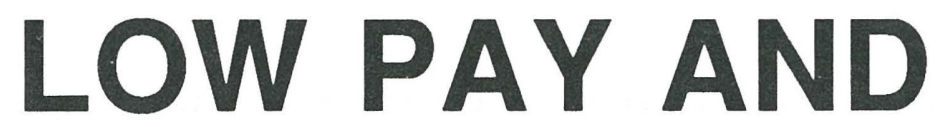 \\ THE MINIMUM WAGE}

Peter Brosnan and Frank Wilkinson

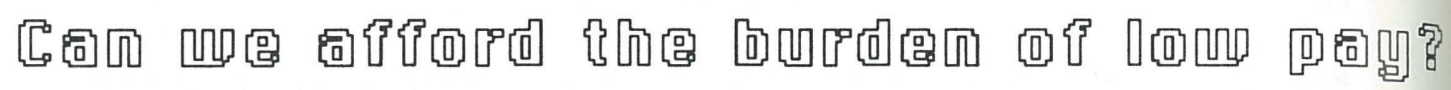

Essential reading for trade unionists, employers, government officials and everyone concerned with equity and efficiency in the economy

A forcefully argued case for a substantial increase in the Minimum Wage

Shows how low paid workers subsidise inefficient employers

Costs carefully, sector by sector, the impact of a realistic Minimum

Contents include:

Who are the low paid in New Zealand?

The Minimum Wage

New Zealand's obligations under international law

Government policy and low pay

Low pay and household poverty

Low pay and the pay equity debate

A case study: The economics of contract cleaning

Low pay and the economy

What would a realistic Minimum Wage cost?

PUBLISHED BY New Zealand Institute of Industrial Relations Research

Industrial Relations Research Monograph No. 2

Price normally $\$ 24.95$ - Special introductory offer $\$ 22.45$

Order from:

Publications Manager

Box 28093

Wellington

The introductory price of $\$ 22.45$ each includes GST and postage in New Zealand. Make cheques payable to: "New Zealand Institute of Industrial Relations Research" 